\title{
SECURITOLOGY - THE CONCEPT OF SAFETY
}

In the article the author presents his own definition of the category of safety, emphasizing both: objective and subjective aspects of this idea. The author, on the basis of available publications, carries out the presentation of securitology as the scientific discipline as well as categories studied within that science, like: security, needs value and sense of safety, risk, danger, personality of a manager, etc. In the article are included proposals of a security model covering objective dangers and the sense of safety.

Key words: securitology, security, science of safety

\section{Aims of the article}

The aim of the article is to review science accomplishments and to present relationships between objective and subjective categories of safety as well as to propose the author's own definition of safety and concept of safety model.

\section{Research problems}

Safety understood as a certain state based on the lack of threat is the subject of interest for many research areas, like: natural science, technical science, medicine, agriculture and social science, as well as particular scientific disciplines with roots reaching the very beginnings of the scientific studies of reality. It is also a practical knowledge derived from many different areas of business activities and every-day life.

For each scientific discipline encompassing more specific research areas within it it is possible to ascribe representatives of these disciplines, their standpoints and publications regarding safety.

First publications undertaking the task of recognizing securitology as a scientific discipline - concerning the problem of safety, date back to the year 1989 - which can be explained by new requirements, expectations and conditions, created after the revolutionary changes of socio-political regimes in Europe. The characteristic feature of these publications is a multidimentional way of perceiving and understanding safety as a subject of research, resulting from the observation that the interactions of threats depend on many different factors, both: objective and subjective, sociopsychological and cultural, political and legal, natural and technical, macro- and microeconomic, remaining in mutual and solid connections

The term: securitology (siekhuritologiya) was used in the year 1989 in Russia by W. I. Jaroczkin [5] who, in a very innovatory manner, pointed at the new scientific discipline being separated from others, the new science about the safety of human life. Among other authors using the word securitology in regard to the science treating safety as the social aim and the subject of research as well as employing adequate research methods, are: Urlich Beck, Jan Buzalka, Tadeusz Hanausek, Victor Porada, Janusz Swiniarski, Stanislaw Piocha, Leszek Korzeniowski, Jan Mikolaj, Ladislav Šimák, Ladislav Hofreiter, and others.

Tadeusz Hanausek uses the concept:"science about the administration of safety" and emphasizes that "whenever thus exists a possibility (at least theoretical) to minimize or eliminate threat by purposeful, regulative human interactions, then the management of safety (opposite of danger or threat), is possible and advisable. Furthermore, since this type of management is possible, it should be based on theory, so the science of safety management should exist and develop [3, p. 37].

The University of Zilina (Slovakia), prefers the name of Security Management "Bezpecnostny Manazment", by which "the specific intelectual activity, directed to reverse or to minimize risk or threats of various nature-regarding life and possessions of citizens, groups and society, is being understood that employs elements of risk management, crisis management, disaster (accident) management, values management” [12, p. 20].

Risk exists here as an auxiliary notion, by some authors it is considered to be a form of threat or danger itself. The research concepts of this university directly point to the substantiality and measurability of risk, thus treating the risk as the measurement of threat, expressing the potentiality of danger. Such understanding of risk gives the possibility of risk management category of "uncertainty" characterized by the lack of possibilities to indicate alternatives and their validity. And thus, Ladislav Šimák defines the risk as "quantitative and qualitative expression of danger, degree or measurement of threat. It is the probability of formation of the negative phenomenon and its results" [14, p. 39]. On the other hand, Jan Mikolaj writes: "Risk as a rule is defined as something unsteady, uncertain - what is bound up with the course of the phenomenon and that disturbs its intentional causation" [13, p. 17].

\footnotetext{
* Leszek Korzeniowski

European Association for Security, Śniadeckich 12 B, 31-531 Kraków, Poland, E-mail: lfk@pp.com.pl
} 
Urlich Beck described a risk society as the one endangered by side-effects of a scientific and technical development. At the same time, conclusions can be drawn that these are not only health consequences for people or nature but as well, social, economic, political side-effects of these side-effects: Market crush, capital devaluation, bureaucratic controls of business enterprises, opening of new markets, gigantic costs, court proceedings, loss of reputation. In the society of risk, gradually or stepwise - by an alarm warning about the smog, an accident with a poisoning substance, etc. a political potential of a catastrophe is being created. (...) The risk society is a society of catastrophe. What threatens it is that "an exceptional state becomes the norm" [2, p. 33]. This is how Urlich Beck, in a most precise way, described the nature of connections: safety - threat - risk: “ (...) risk society. Its normative antiproject that lays at its basis and drives it is the safety" [2, p. 64]. The normative antiproject of safety is non-safety (threat).

Based on the analysis of literature and the scale of dangers threatening a person, conclusions can be drawn about the lack of sufficient theoretical basis in the area of needs, values and subjective sense of safety of individuals, social groups as well as humanity. It also appears that in spite of advances in the sciences of physics, geophysics and others, as well as in spite of the enormous progress in technique and technology, the objective state of safety has not still been developed enough nor is sufficiently predictable. Earthquakes, tsunami-waves and other elements still engulf thousands of victims among people and cause immense losses in their property.

If it can be acknowledged that the research of certain categories has contributed to a marked decrease of loss or even control of threats (for example, the category of risk in banking), it also has to be said that the problem of the objective category of dangers and the sense of safety still require further research and exchange of scientific ideas among various scientific centers from all the continents, and especially from Europe.

\section{Securitology - the concept of safety}

Science is a highly specialized exploring activity conducted by scholars and aiming at objective exploring and understanding the environmental and social reality and at creating premises for using the acquired knowledge in order to transform the reality in accordance with human needs [11, p. 12].

Security apprehended as a state of lack of risk, is a subject of interest of many areas of science such as natural, technology, medical, agricultural, social and also particular scientific disciplines dealing with ancestry reaching the beginnings of scientific recognition of reality.

Safety means a certain objective state understood as a lack of danger, sensed subjectively by individuals or groups $[6, p .183 ; 9, p$. $21 ; 10$, p. 437]. It should be noticed that the world: "state" is very closely related here to the concept of situation which describes the configuration of common relations between humans and other elements of their environment within a certain period of time.
When analyzing this kind of relation from the point of a human (who is one of its elements), we can say that the "state" means here that the subject of the situation may also be non-human.

Victor Porada defines the state of safety as a system of bound up together and interdependent to various degrees factors and their characteristics that decide about the health, the life and all other values in a certain society (form of government, freedom, faith, property, etc.) $[19$, p. 263]. Negative phenomena are, as a rule, described and penalized in the country's legislature.

The meaning of the word "safety" is related here to the subjects marked by this title (designators of this title). The entirety of these subject (designators) constitutes the range of the name. The word: "safety" is derived from Latin: sine cura (securitas) [22, p. 27] and in contemporary dictionaries it means: "the state of nonthreat, calm, certainty" [20, p. 147] or: "the psychological or legal state in which an individual has the sense of certainty, support in another person or in the proficiently operating legal system; the opposite of threat" [21, p. 50]. Thus, the designators of the concept of "safety" are the set of contradictions to "threat".

Threat is a potential reason of an unwanted state. Threats are not the category by themselves because they always relate to a certain subject to which they apply their destructive character. They may cause negative consequences because each subject (a person, a system, an organization, the vastness of nature), is characterized by a lower or higher susceptibility, certain weaknesses that make it possible to change a potential threat into the harm.

For the purpose of generating threats, certain possibilities are necessary which are contained in the subject itself, in its surroundings or in the relation between the subject and his/her surroundings. This kind of threat can be characterized by a negative potential (destructive, threats), understood as an ability to destructive reaction to the system.

Victor Porada emphasizes that the state of safety bound up with the environment, in which it is created, progresses and develops further. The environment may have a character such as: geographical, social, political, etc., or the combination of these. The sources of threats and conditions of the environment determine the state of safety, circumstances have rather accidental character and may, but do not have to, influence the course of action directly [19, p. 263].

The definitions of safety concept concentrate on its objective and subjective aspects.

- The objective state of safety relates to the existence or nonexistence of real threats independent of anybody's perception. These will be the threats caused by:

1. inanimate nature independent of a person (for example: space objects, Earth's tectonic plates movements, volcanoes, typhoons),

2. animate organisms (microorganisms, plants and animals),

3. human products (for example: buildings, machines, equipment, chemical substances, explosives), 
4. human and society (tensions in interpersonal relations, conquests, slavery, religious wars, terrorism). It may be real activities of other participants of social life, unprofitable and dangerous to the vital interests and the basic values of an individual, a group, a society or the whole mankind.

- The sense of safety is the expression of a subjective aspect and relates to the consciousness of existence - the lack of it or the lack of awareness of any possible contraction to the danger.

\section{Model}

In reality, we often come across a situation in which the individual's behavior even if agreeable with the perception of reality, and not with its objective features, results in objective features and not perceived or imagined ones. Modern technique of registry has shown tragic situations being such a problem $\left(26^{\text {th }}\right.$ of December, 2004 - following the earthquake in the nearby of the Indonesian Island of Sumatra, a gigantic tsunami-wave was created. The number of fatalities was estimated at over 300000 , wounded at a few millions. It was perceived that the environment was friendly, safe.

The essence of this situation is the fact that people were facing the threat that they could not see, but which existed in reality).

The objective features shape the person's behaviour depending on how he/she sees his/her situation while the understanding of a situation by an individual depends on:

a) what the objective features of the environment are,

b) what his/her own characteristics are, and

c) what course of action he himself/she herself takes.

Furthermore, certain elements of a situation influence a person directly, without the intervention of an individual's consciousness, for example if, estimating the situation as being safe he/she will not react then he/she will be hurt accordingly to the objective characteristics of the threat and not the imagined features of the environment.
Taking into consideration the relations between the objective and subjective aspects of safety, it is possible to design a model consisting of four segments:

A. State of safety when the external threat is little and is perceived as low.

B. False safety when the external threat is high, but it is perceived as low.

C. Threat (lack of safety) when the external threat is high and the perception is correct (adequate).

D. Obsession when the external threat is low but it is perceived as high.

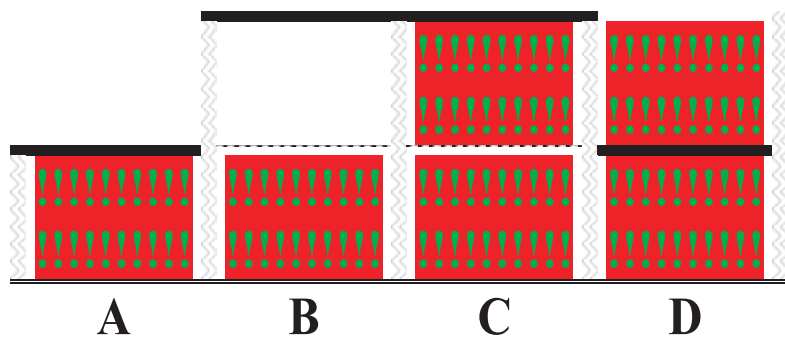

\section{Conclusions}

The analysis carried out has shown that safety has its objective and subjective aspects. Securitology, a new scientific discipline being created, undertakes the research of objective situations as well as needs, values and sense of safety. As results from the undertaken by the author analysis, the sense of safety in the closest surrounding shapes itself differently from the general scale. The author explains this feature with a subjective factor - being intensified by a character of information in mass media (that does not have any influence on the sense of safety in known, personally, local environment).

The proposed safety model, taking into consideration objective threats and the sense of safety, can be useful to describe scientific research and management procedures.

\section{References}

[1] BUZALKA, J.: Certain problems of the crisis management theory and the civil security, (in Slovak), Akadémia Policajného zboru. Bratislava: 2001.

[2] BECK, U.: Society of risk. On the way to a different progress, (in Polish), Wyd. Naukowe SCHOLAR, Warszawa 2002.

[3] HANAUSEK, T.: The safety management - a new branch of science, (in Polish), Bezpečnost a ochrana majetku, LIPORT LFK, Kosice 2001.

[4] HOFREITER, L.: The safety management, (in Slovak), FŠI ŽI, Žilina, 2002.

[5] JAROCZKIN, W. I.: Securitology - the science of life safety, (in Russian), Moskva 1989.

[6] KORZENIOWSKI, L.: Management. Fundamentals of administration, (in Polish), EAS, Kraków 2003.

[7] KORZENIOWSKI, L.; The safety management, (in Ukraine), Aktualni problemi ekonomiki 2004, No. 1(31), 147-154.

[8] KORZENIOWSKI, L.: The safety management, (in Polish), Gumanitarna paradigma oswitnych ta ekonomicznych procesiv u svitli koncepcji ewropejskoi bezpeki, REGI, Rivne 2002, 68-77;

[9] KORZENIOWSKI, L.: The safety management. From a risk to the system, (in Polish), Zarządzanie bezpieczeństwem. Prace Edukacyjne, red. Leszek Korzeniowski, LIPORT LFK, Kraków 2001. 
[10] KORZENIOWSKI, L.: The safety management. Market, risk, threat, security, (in Polish), Zarządzanie bezpieczeństwem, PSB, Kraków 2000.

[11] KRZYŻANOWSKI, L.: The science of management - the foundation, (in Polish), PWN, Warszawa 1985.

[12] MIKOLAJ, J., HOFREITER, L., MACH, V., MIHÓK, J., SELINGER, P.: The safety management - terminology, (in Slovak), Výkladový slovník, Multiprint, Košice 2004.

[13] MIKOLAJ, J.: The risk management, (in Slovak), RVS FŠI ŽU, Žilina 2001.

[14] ŠIMÁK, L.: Crisis management in public administration, (in Slovak), Žilinská univerzita, Žilina 2001.

[15] OLCZYK, E.: The Poles are afraid of offenders, (in Polish), Rzeczpospolita 2003-04-14.

[16] Social opinion. The world less safe, (in Polish), Rzeczpospolita 2004-01-09.

[17] PIOCHA, S.: Macroeconomy and problems of security, (in Polish), Problemy bezpieczeństwa ekonomicznego wobec procesów globalizacji, red. naukowa Stanisław Piocha, PTE, Koszalin 2004.

[18] POLEDŇÁK, P.: The protection works in municipal aglomerations (in Slovak), Riešenie krízových situácií v špecifickom prostredí, Žilinská univerzita v Žiline, Žilina 2002, III. 123-132.

[19] PORADA, V.: Theoretical analysis of the police information, situation and identification of the police action, (in Czhech), Sborník Policejní akademie ČR, Praha, 2000

[20] The Polish dictionary (in Polish), PWN, Warszawa 1979.

[21] The dictionary of contemporary Polish, (in Polish), Reader's Digest Przegląd, Warszawa 1998.

[22] ŚWINIARSKI, J.: The philosophical basis of safety education (in Polish), Egros, Warszawa 1999.

[23] ZIĘBA, R.: The establishment of european safety, (in Polish), SCHOLAR, Warszawa 2004. 